\title{
FIVE LESSONS FROM EUROPEAN DEMOCRACY
}

\begin{abstract}
:
Outside of some states still struggling with post-communist transitions, Europe itself may be the first European democracy to collapse in decades. Though never a bastion of participatory democracy and even subject to continuous criticism due to its democratic deficit, the European Union (EU) has provided hope to those who envision a post-national democratic political community. As such, whether the EU survives its present crisis or not, cosmopolitan democrats will look to the EU as a vindication of their ideals. Though perhaps surprising given their track record, this paper will argue that political scientists, especially those concerned with democratization, can also be optimistic about what the EU has brought to the table in terms of how we conceive processes of democratic development. Throughout the paper it will be demonstrated that the creation and maintenance of the European democracy has challenged much of the literature's fundamental assumptions of what makes democracy work. Five key lessons from the European democratic experience will be presented in an attempt to disrupt some of these assumptions including lessons regarding the diversity of the demos, the contingency of democratic upkeep, the challenges of the state, the role of elites in political transformation, and the necessity of exclusion within inclusive spaces. Though a general theory of democracy will not be presented, suggestions will be made as to how we can incorporate some of these lessons into the dominant approaches to democracy found in the literature.
\end{abstract}




\section{Introduction}

For the casual North American observer, the European Union (EU) appears as a political and economic entity which has seemingly gone from crisis to crisis. From early questions of legitimacy, to the failure of the Constitutional ratification referenda in 2005, to the current Eurozone debacle, the EU has not been subject to the most positive press, especially over the last decade. However, insiders, directly involved in the processes of integration and the evolving operations of the EU as well those who have dedicated much of their time and energy to understanding this evolution, certainly have a more balanced view. Indeed, the EU has been posited as something worth striving for and, in times of crisis, saving for the simple reason that the union has provided both participants and onlookers with a sense of hope when it comes to solving old political problems and, for some, even the possibility of a post-national progressive space (Rifkin 2004; Levy, Penksy and Torpey 2005).

However, one of the biggest debates which has continued throughout the EU's history is the question of the democratic deficit. Certainly the more powerful institutions of the Union such as the European Commission are less directly democratic than the less powerful ones such as the European Parliament, and even within those more democratic but less powerful institutions, participation in them by the European demos (if there exists such a thing at all), is quite low. Yet it is here that I am willing to suggest that the European Union has arguably been a success when it has come to democracy, albeit in a less conventional sense. Despite its shortcomings in terms of substantive participation, the European Union exists as one important case which has challenged older assumptions about the conditions necessary for democratic institutions, procedures, and law to take root and be sustained. In doing so, the EU has not only opened up the possibility of thinking about the development of democracy in an altogether different way, it has also opened up the possibility of further democratic expansion in different locales across the world. The development and sustenance of democratic laws and institutions should not be understood as being restricted to particular conditions such as socio-economic and class compromises or the appropriate general political culture. It is the purpose of this paper to demonstrate this point while remaining committed to a critical analysis of the democratic processes that the EU has exhibited. As history has shown, democracy is no panacea for political or socio-economic problems and in some cases has even contributed to them.

Of course, the word democracy carries with it a plethora of competing meanings in political studies. As previously stated, the European Union is often seen as a fundamentally undemocratic entity due to its powerful elite institutions and its low levels of participation from the European citizenry (Georgi, von Homeyer and Parsons 2006). Others claim that the EU is not democratic because it does not represent the general will of a sovereign people and that, at this time, only the EU's Member States can truly claim democratic legitimacy (Georgi, von Homeyer and Parsons 2006). Radical critiques would point to the fact that ordinary citizens do not see this democratic space translated into real control over social and economic processes and view the EU as another apparatus of vested interests (Giorgi, von Homeyer and Parsons 2006). Of course, if these are the measures through which European democracy is evaluated, cases can most certainly be made for the EU's lack of democracy. Yet, despite all of these, it must not be stated that the EU completely lacks any democratic credentials whatsoever. Important features which have historically been heralded as democratic do exist when it comes to the functioning of the EU's governing institutions; features including the ability of citizens to participate freely in the political process through the European Parliament and the ability of citizens to freely oppose the directives of the 
EU without being repressed or reprimanded. Rather than simply mechanical aspects of what some would pejoratively call mere procedural democracy, these features carry significant normative weight as they are founded on the notion of the political equality of human beings. With that said, procedural democracy must be viewed as something of great value in-itself.

However, the European Union cannot be exclaimed as a democratic success simply because of this. Indeed, all of its Member States had achieved these types of democratic credentials before joining the EU and likewise many states around the world have similarly achieved this level of democracy. Instead, what can be described as an achievement for the European Union is not what has been achieved, but rather how it has been achieved. Indeed, the EU has challenged some of the most basic assumptions about what allows democracy to come into being and what allows it to be maintained. Specifically, the EU has been able to challenge many of the frequently posited necessary conditions for democracy that have been laid out by scholars of democracy and democratization over the last few decades, showing that, indeed, democracy can be done in a different way. So what exactly is it that the EU has challenged and what are its implications? It is my contention that the challenge which the European Union brings to many of our current understandings of democracy and democratization can be seen clearly through five lessons that the EU has taught us through its historical process of democracy building. With this task we will soon proceed.

However before any of that is possible, we must first clearly define what is meant when we speak of democracy. Specifically, what are the characteristics that make what we are calling democracy what it is? Given what has been already stated about the normative importance of procedural democracy and given that the case of the EU can shed new light on the requirements for such a democracy against much of the established literature, a definition which encompasses essentially procedural elements will be employed. Thus, when speaking about democracy, what will be meant is a system of government whereby a) political rule is not arbitrary, but rather authorized by the polity's constituent population (however institutionally arranged) through regularly held competitive elections and b) opposition to this political rule and the expression of this opposition, given that it too does not attempt to rule arbitrarily, is respected as legitimate and not politically repressed. From here the five lessons from European democracy can be elucidated.

\section{Lesson 1: Democracy does not require the existence of a uniform political culture, only a negotiated compromise between divergent political cultures}

For authors as diverse as Seymour Martin Lipset, Gabriel Almond, and Robert Putnam, all who have contributed quite substantially to the democratization debate, democracy is understood as being produced and upheld through the development of a common democratic political culture, albeit for different reasons and through different processes and mechanisms for each author. Yet however a given polity gets to this appropriate political culture, a situation is created whereby citizens view themselves as such in perhaps its truest sense and participate in the polity's political issues and institutions due to their civically-inclined attitudes (Lipset 1994; Almond and Verba 1989; Putnam 1994). Lipset (1994) for example, in his revisiting of the social requisites for democracy, suggests along classic modernization theory lines, that a polity's turning away from more traditional modes of organization and towards more common and civic forms is crucial for the weakening of divisive and contentious tendencies amongst the population which could otherwise result in undemocratic forms of political domination. The establishment of a 
stable democracy for Lipset (1994) thus requires a high degree of common orientation. Almond and Verba (1989) in their Civic Culture likewise place a large focus on the necessity of consensus for a democratic polity when it comes to the values and attitudes that are upheld within a citizenry. As a part of this consensus of "participatory culture" a general engagement with institutions must be forged with both a respect for internal diversity and a balancing of modern and traditional norms under a common civic umbrella in order for democracy to come to fruition (Almond and Verba 1989). Putnam (1994) as well, especially within his account of civic attitudes in modern Italy, also pinpoints the existence of a common culture as key for democracy to take root and be sustained. In his comparison of regions within the Italian state, he finds that those regions which have high participatory attitudes and a culture of civic engagement tend to fare better in terms of his measurements of democratic performance than those regions which have less of a culture of engagement (Putnam 1994). As such, for all of these scholars, despite their substantial differences in terms of cases and aims of their research agendas, a general political culture of civic orientation and engagement is central for the establishment and upkeep of a democratic system of government.

It is here, however, that the experience of the EU can offer an important intervention into this one major approach. Slightly against the grain of these aforementioned thinkers, as the EU has demonstrated, the establishment of a democratic system often relies more heavily on the perpetual negotiation of plurality, along with its eventual compromise, as opposed to either its withering way or the existence of a strict commonality. Here, the processes of democratization at the EU level, both historical and ongoing, provide a social phenomenon that acts somewhat like a microscope, allowing us to "zoom in" and "enlarge" the field of analysis to pinpoint important developments that can be more difficult to identify at democratization studies' more frequent level of analysis: the state or national level. At the European level, it is clearer to see that European integration, both at its origins and through its expansions, as well as through the subsequent implementation of more explicit democratic institutions such as the European Parliament, has not happened on the back of a common political culture across 27 Member States.

Even at the very beginning of the continental integration process, the eventual expansion of the European Coal and Steel Community (ECSC) into the European Community required negotiation and deal making across Western European states. This process of course was not simply one of deal-breaking between identical elites across different states, but between actors who were situated in particular national or sub-national political cultures, with their own values, norms, and ways of doing politics. In more recent times, with the advent of the EU, the need for compromise between divergent political cultures across European states has become more pertinent, with accession into the Union resting upon candidate states' ability to abide by democratic norms according to the acquis communautaire. With the new Member States of Eastern Europe having engaged in post-communist transitions over the past 20 years, this has required the respective Eastern governments to implement greater anti-corruption measures, democratic reforms, and sometimes, the admission of crimes committed by previous regimes. While this has required a shift in the way that some states conduct themselves domestically, this has been a process of negotiation and compromise rather than of wholesale societal transformation. As such, processes of democratization that have rested upon rules of accession have not entailed a wholesale shift away from the particularities of their own political norms. Since these particularities remain, the fact that negotiations and compromises have the potential to be reversed based on the future manifestation of these particularities must not be discounted. 
Although it can be said that a common commitment to democratic norms is necessary for EU integration as well as democracy, such a necessity is not developed across states through political cultural commonality but continuous negotiation between states and their norms. Indeed, the continuation of European governance in its 27 state form, including through its democratic institutions, requires that Member States maintain their commitment to these norms.

Yet, of course, this in turn relies upon the negotiation and compromise across divergent political cultures within Member States. It is here that the EU provides us with an insight into how we can analyze processes of democratization in a new way, within the traditional level analysis of Member States. As the case of the EU shows, what can appear as commonality is often in reality the result of continuous compromise and agreement between divergent actors. Just as it is incorrect to speak of a common political culture in the EU, is it also incorrect to speak of state or national political cultures, whether in terms of civic orientation or participatory tendencies, in such homogeneous terms.

For these aforementioned authors including Lipset and Putnam, however, meaningful diversity at the state level is problematically viewed as having been eroded either through processes of modernization or weakened through the development of civic traditions, rather than perpetually existing and being continuously negotiated. As such, they have remained unable to account for instances whereby diverse groups clash within a democratic system, sometimes pulling the system apart and into an authoritarian outcome. Though political culture is certainly an important factor for actors' behaviour since it provides meanings through which agents act, a single overarching political culture can never permanently engulf an entire polity and determine citizens' political behaviour. Societies are always divided along various social, cultural and political lines, which can come to manifest themselves politically if divisions are not negotiated properly. As such, when it comes to the reasons for the existence of a democratic system of government, what is often attributed to the formation of common civic orientations, or even a culture of respect for diversity, should instead be understood as the product of more contingent negotiations between diversity which, in leading to compromise, often gives off the appearance of commonality. In short, these accounts, which focus on a holistic political culture, end up facing difficulties as they misrecognize stable, yet negotiated and contingent, configurations of diversity for a situation of homogeneity. The EU example shows that, in order to understand how a democratic system is established, the negotiation of plurality must be taken seriously as a factor.

\section{Lesson 2: Negotiations and subsequent compromises conducive to producing democratic outcomes are always contingent rather than structurally determined}

Other authors who have conducted empirical observations of the conditions necessary for democracy may have rightly viewed social plurality as an important element to be negotiated for the consolidation of democracy, but have instead recognized it solely in terms of class or economic negotiation. Some of the authors in this more structural school of thought have included Moore Jr., Pzerworski and Limongi, Acemoglu and Robinson, Rueschemeyer, Stephens and Stephens, and Carles Boix. Even Charles Tilly, who through his process-oriented approach has tried to move beyond some of the limitations of a structural approach, categorized the insulation of categorical inequality from politics as one of three key variables for democratization and, as such, must be included within this approach. In these studies of democracy, economic determinacies are central with particularly defined class and economic 
compromises understood as producing democracy and, in other cases, dictatorship. For example, such explanations include democracy coming to fruition through factors and developments such as the existence of a large middle class, the incorporation of the working class into the welfare state, or a more generalized greater level of income parity (Moore 1966; Przeworski et al 2000; Acemoglu and Robinson 2009; Rueschemeyer, Stephens and Stephens 1992; Boix 2003; Tilly 2007).

According to Barrington Moore Jr. (1966), author of the now classic Social Origins of Dictatorship and Democracy, the development of a democratic system of government is explained as historically relying on the ascendency and eventual dominance of the bourgeois class relative to other classes within the same state. Quite simply, for Moore (1966): no bourgeoisie, no democracy. Other scholars who have followed Moore in his historical sociological approach such as Rueschemeyer, Stephens and Stephens as well as Carles Boix have also put forth a similar structuralist account, though with crucial modifications. By expanding the scope of the historical case studies into other regions, most notably Latin America, Rueschemeyer, Stephens and Stephens (1992), along with Boix (2003), have demonstrated how it has in fact been the ascendency and incorporation of the working class into official sociopolitical institutions that has been the determining factor for democratization. Others have even modified this further, abandoning the explanatory dependency on a specific class and opening up the explanation to one in which the general dynamics of inequality determine a state's regime outcome. For Acemoglu and Robinson (2009), and Pzerworski and Limongi (2000), for example, who employ game theoretical models very centrally in their analyses, a particular threshold of socioeconomic inequality is sufficient to determine whether a regime will be dictatorial or democratic. Charles Tilly (2007), who in his work Democracy has utilized more qualitative historical analyses, presents an explanation for the maintenance of democracy whereby the question is not whether socioeconomic, or as he calls it, categorical, inequality is kept within a certain limit but one of whether public politics has been insulated from this inequality.

These approaches certainly face challenges when presented with an analysis that places the EU front and centre. This is both with regards to the now legally necessary democratic outcomes within individual Member States, negotiations between elite, as well as the actions of EU citizens within official institutions such as the European Parliament and in what has been described as European civil society. First of all, much can be learned from the confrontation of class or economic compromise accounts of democratization with the histories of democracy in the Member States. With 27 divergent histories of democratization, some stemming from so-called bourgeois revolutions, others having come out from military dictatorships, and a large number having transitioned from socialist regimes, the suggestion that democracy in European Member States has been the result of one particular class or a particular economic threshold is an untenable one. As such, though democracy in the EU has relied on democracy's sustenance in its Member States, the processes have been too diverse to rely on a single economic explanatory variable.

With regards to what keeps European democracy functioning across Member States, whether in terms of elite negotiations or in terms of the demands of different Member State citizens in European civil society, economic or class compromise has not been something that has been central in the upkeep of the common political structure. In terms of elite negotiation, with poorer countries having looked towards the economic benefits of the Union's market, there has been little talk of policy being aimed at economic levelling between nation-states. More notable however is the fact that there have been very few expressions of this desire among citizens in 
Member States, despite the inequalities in wealth between countries (Petrakos et al 2005). Nonetheless, however, democracy has been able to survive. Finally, in terms of the effects that the continental horizontal class division has had upon democracy, the result has been the same. Despite the fact that some on the European left have pushed for a "Social Europe"-thicker economic regulations and social policy at the European level to offset the inequalities of the marketplace-policies have not been implemented to the extent that serious inequalities in Europe are no longer a problem (Daly 2006). Yet, despite the fact that they are still prevalent and, in many cases, have increased over the last several decades, this has not had an impact on European democracy or on democracy in the Member States-at least not yet.

\section{Lesson 3: Democracy does not necessarily require the elimination of autonomous centres of power.}

In much of the academic literature on democracy, the idea that democratic systems exist within states is often simply assumed, with comparativists dedicated to analyzing one state-bounded system in contrast to another. Since democracy has historically been territorially consolidated within states, there has been an implicit understanding in many works that the existence of a consolidated state remains a condition for democracy despite this fact frequently not explicitly appearing in much of the literature, including in those schools of thought which have been previously discussed. In many ways, the territorial state has become so normalized that it has become difficult to understand democracy in any other way. Despite this, however, other authors in contrast have been much more explicit in terms of the need for a state, and particularly a strong one, for the existence of a democratic system (Tilly 2007; Sorensen 2007).

Georg Sorensen (2007) in his Democracy and Democratization stresses the importance of the consolidation of state power in the Weberian sense as being one of the, if not the, most important developments necessary for democracy to take root and be sustained. Without such a development, divisions of coercive power are likely to result in politics being played out external to parliamentary and deliberative institutions (Sorensen 2007). Likewise, Tilly (2007), also in his more recent work Democracy, posits a similar claim to Sorensen, historically demonstrating that the reduction of autonomous centres of power is conducive to democratization whereas their strengthening results in what he labels de-democratization. This is due to the tendency for autonomous groups to coercively compete for state power when such capacities are available for deployment.

With the case of the EU, however, both the implicit and explicit understandings of the role of the state in democracy have been radically challenged. In terms of implicit understandings, the EU has given authors much to think about since it has expanded the democratic imaginary and passed the traditional territorial boundaries of the nation-state. In doing so, the EU has challenged more limited accounts of what makes democracy possible and has in turn demanded more expansive explanations of this democratic outcome than simply the interaction and relationships between state-bounded actors. Most obviously, on top of these various bounded conditions that many of the aforementioned authors have put forth, the role of interstate relationships that the EU has made obvious - relationships between actors with the capacity for violence-has become an important variable in its own right that needs to be unpacked.

Perhaps more importantly, those authors who have been more explicit in their understanding of the role of the state in democracy have also been fundamentally challenged along similar lines. For these authors, the existence of diverse actors who possess coercive capacities has 
already been understood as being crucial for democratic outcomes, and thus is not a new revelation. What is new however is the fact that democracy remains a possibility despite the existence of these autonomous coercive power centres. As previously stated, for authors such as Tilly (2007) and Sorensen (2007), the disappearance of these autonomous centres is posited as a condition for democracy as their existence often triggers political issues between divergent forces being solved via coercion rather than through more civic channels under a monopoly of coercion.

However, as the EU case has demonstrated, autonomous power centres are not necessarily a detriment to democratic relations or institutions becoming successfully utilized between divergent groups. As the history of European integration has demonstrated, autonomous power centres such as states do have the ability to negotiate with each other and come to agreement about models of cooperation, including democratization across state lines. Although the European integration process has been a historically specific project and cannot easily be applied to other regions, the fact remains that there is nothing inherent about autonomous power centres that make them inhospitable to democratization beyond their reach. Rather, what fundamentally does matter and will determine the possibilities for larger projects of democracy, such as that of the EU, are what those in control of the means of coercion wish to do with their power. One element that this condition does fundamentally change, however, is our understanding of how democracy can be torn apart. Rather than being cancelled out with the repressive act of a single centre of coercive power, autonomous power centres can put larger democratic formations into jeopardy through secession or, in the worst scenario, war.

\section{Lesson 4: Elites can be democrats too.}

In much of the literature, including in both the class configuration and political culture types of argumentation we have seen, democracy is frequently being posited as a bottom-up process. For the political culture analysts, democracy is viewed as an outcome that will not come to fruition without a culture of civic engagement among the citizenry. Otherwise, in their view, politics will unfold solely through the wishes of the elite, producing forms of authoritarianism and elite corruption. Likewise, in terms of the class configuration school, democracy is understood as a bottom-up process coming as a demand from the subordinate classes, with the elite only giving in to the establishment of demanded democratic institutions if their particular class interest can be maintained. The elite thus are not viewed as wanting to establish democratic institutions for their own sake. Schools of thought, including the consociational approach developed by Arend Lijphart and the elite-pact approach originally brought into discussion by Guillermo O'Donnell and Phillipe Schmitter and subsequently taken up by other democratization scholars (Pzerworski is also an important figure here), have also tended not to view elites as true democrats in their own right. Rather, elites are posited as pursuing their own interests and, more specifically, their own political and economic projects independent of any primary concern for a democratic regime outcome (Lijphart 1969; O'Donnell and Schmitter 1986). Democracy, if it comes to fruition, is viewed as the mere residue of a balancing between other elite interests and not as the result of any desire for a democratic system itself.

Here it can be said that the development of democracy in the EU has turned these assumptions on their head. In terms of a general tendency, what began as an elite project with the ECSC has continued as an elite project with major developments of further integration having been pushed along by the EU's top institutions such as the Commission, rather than having 
originated from more popular forums. In terms of the origins of the EU's more directly democratic institutions such as the European Parliament, this has also been the case. Unlike many historical examples of the implementation of parliaments or assemblies which were frequently fought for by members of the populace and awarded as a form of concession by the elite, with the European Parliament, implementation was just the opposite. Seeing that the EU was needing further channels of democratic legitimation, direct election for and strengthening of the European Parliament were put into place without mass mobilization on the part of the European citizenry. Rather, as part of a larger effort at "building" Europe along with the attempts at constructing a common European identity and citizenship, there has been an effort to build a common European democracy (Rittberger 2005). With this, as oxymoronic as it may sound, the case of the EU has shown that elites can be democrats too.

Likewise, this also has important implications for the frequently expressed notion that democratic systems depend upon popular consent. For although substantive participation in the EU is generally low among its citizens it cannot be said that the democratic aspects of the integration project will simply slip away if they are not utilized by the European citizenry. Although it can be argued that a lack of participation is not helpful when it comes to the question of substantive legitimation, it has played no part in the EU becoming less institutionally democratic. In fact, because of the impetus from the elite, who firmly believe in the process of democratizing the EU, the channels for participation within European institutions have increased rather than decreased. Here the EU can provide one possible explanation for the continuation of procedural democratic systems across global northern countries. Although political participation, especially in terms of elections, has declined substantially over the last 30 years across nearly all developed countries (Blais, Gidengil, Nevitte, Nadeau 2004) procedural democratic institutions have held up from the top despite a shrinking participatory foundation from below. For reasons that ought to be further explored, elite engagement in procedural democratic norms has persisted despite this tendency of the citizenries.

\section{Lesson 5: Democracy fundamentally rests upon the subordination of some groups, varying in terms of degree and content}

The idea that democracy is, by nature, an exclusionary form of governance is a critique that has been taken up more readily by contemporary political theorists than by those who study democracy via the lens of comparative politics or political sociology. Chantal Mouffe (2000), for example, in borrowing from Carl Schmidt's understanding of the democratic paradox, has argued that the formation of any democratic system necessitates the drawing of a line around a given demos, defining who is included and who is excluded. As such, despite its emancipatory appeal, democracy rests upon this fundamental division. Others, such as Etienne Balibar (2004), have directly applied this notion of demos-making to Europe itself, suggesting that it has resulted in the construction of a tiered citizenship with those unable to obtain official documentation based on Member State belonging, facing exclusion from the EU's democratic project despite living, working and contributing in European space. Although scholars of citizenship have often focussed on this tension within nation states, once again, it has been the EU that has magnified a particular problem. Whereas studies of political formations of the past have never highlighted this process of exclusion as central to the foundation of democracy, the EU, with its newly instituted project, has demonstrated the existence of this process as an unavoidable factor. 
However, the EU has also shown that subordination does not simply equate to absolute exclusion from the project. As in every democracy, the legitimacy of the system rests upon the opposition agreeing to the rule of the government, often taking the shape of the minority agreeing to the rule of the majority (Dahl 1971). To ensure that the democratic system is safeguarded against a revolt from below, defensive coercion from above, or even secession, those who are not in power must feel sufficiently satisfied with the state of affairs overseen by those in power. The upkeep of this situation, however peaceful it may be, does require a degree of subordination, whether simply in terms of political power, or often more expansively in terms of other social categories including socio-economic, socio-cultural, religious, racial, gender-based or, in the case of the EU, national position. Indeed, democracy has its winners and its losers and in understanding how democracy both comes to fruition and is subsequently maintained, we must continually keep a close eye on the changing dynamics and interplay between winning and losing, dominant and subordinate forces. This dynamic, of course, is not unique to the EU. Yet once again these dynamics which are at play across such diverse cleavages in the European polity shows the key relation of subordinations to democratic outcomes in a larger setting, rerevealing particular circumstances that may go left unnoticed in what are normal "units" of analysis in the nation-state.

\section{Looking at Democracy Differently}

For those who have been committed to developing an understanding of how democracy comes to fruition, these five lessons from the European Union's ground-breaking democratic experiment provide much to think about. When put into conversation with some of the existing accounts of democratization that have been discussed here, these lessons have the potential to push our understanding of political outcomes further, potentially towards a reformulation of existing approaches and models. With the EU case having broken down many essentialisms which have been endemic to the study of democracy, we can begin to move forward with an approach that is more open to contextual and contingent relationships between important forces at hand rather than broad-reaching theories which assign pre-defined value roles to particular groups including classes, masses, the elite, or even entire nations. The goal that stems from these lessons thus is to design new frameworks of understanding which can encapsulate these contingencies into an overall reformulated democratic theory. Though such an undertaking is an ambitious task, the developments of the EU have provided us with certain directions which we can follow when it comes to analyzing more traditional units of analysis. As such, these lessons can have a formative role in terms of theory building.

Beyond these more academic purposes however, the case of democracy in the EU, especially in terms of how it has come to be, also has some very positive normative implications. With the EU demonstrating that democracy fundamentally rests upon the identities and capacities of groups, as well their relationships with each other, the question of "who can have democracy?" can no longer be answered in terms of certain societies which possess a certain political culture, class configuration, or state-bounded existence. Indeed, the case of the EU shows that democracy could potentially exist in a multiplicity of situations, as long as contending groups, whatever their makeup, can come to an agreement upon it. Quite simply: no agreement, no democracy. Yet despite this existing as a restrictive condition itself, it is a flexible one and shows that democracy 
has the potential to be constructed across a variety of fragmenting cleavages. Importantly, it also goes to show that the establishment of a truly democratic system-one that is inclusive across a polity — has little chance of succeeding through coercion, whether originating internally or externally.

Equally as important, the EU forces us to take a serious look at the exclusionary underbelly of democratic formations. Although often used as a type of silver bullet in political rhetoric, democracy in itself is no perfect solution for having all voices heard or represented in a single political space. As stated, although this has been a frequent criticism made by political theorists, it has not featured so heavily in empirical or explanatory accounts of democratic formations. Here too, the EU has magnified a more general problem and, in doing so, has created space for us to examine exclusions and subordinations as part and parcel of democracy and democratization itself. Thus, in borrowing an approach from more critical investigations of EU's democratic enterprise and applying it to other polities, not only are we able to pinpoint processes of marginalization, but we are provided an opportunity to reimagine representation and inclusion in new ways. As such, whatever may come of the European Union, we can at least hope that we will be able to learn from a few of its lessons. 


\section{REFERENCES}

Acemoglu, Daren and James A. Robinson. 2009. Economic Origins of Dictatorship and Democracy. Cambridge: Cambridge University Press.

Almond, Gabriel and Sydney Verba.1989. The Civic Culture. New York: Sage Publications.

Balibar, Etienne. 2004. We, the People of Europe? Reflections on Transnational Citizenship. Princeton: Princeton University Press.

Blais, Andre, Elisabeth Gidengil, Neil Nevitte and Richard Nadeau. 2004. "Where Does Turnout Decline Come From?” European Journal of Political Research. 43(1): 221-236.

Boix, Carles. 2003. Democracy and Redistribution. Cambridge: Cambridge University Press.

Dahl, Robert. 1971. Polyarchy. New Haven: Yale University Press.

Daly, Mary. 2006. “EU Social Policy after Lisbon.” JCMS. 44 (3): 461-481

Giorgi, Liana, Ingmar von Homeyer and Wayne Parsons (eds.). 2006. Democracy in the European Union: Towards the Emergence of a Public Sphere. New York: Routledge.

Lijphart, Arend. 1969. “Consociational Democracy.” World Politics 21 (2): 207- 225.

Lipset, Seymour Martin. 1994. “The Social Requisites of Democracy Revisited.” The American Sociological Review. 59 (1): 1-22.

Levy, Daniel, Max Pensky and John Torpey (eds.). 2005. Old Europe, New Europe, Core Europe. New York: Verso.

Moore Jr., Barrington, 1966. Social Origins of Dictatorship and Democracy. Boston: Beacon Press.

Mouffe, Chantal. 2000. The Democratic Paradox. New York: Verso.

O'Donnell, Guillermo A. and Phillipe C. Schmitter. 1986. Transitions from Authoritarian Rule: Tentative Conclusions about Uncertain Democracies. Baltimore: John Hopkins University Press.

Petrakos, George et al. 2005. "Growth, integration, and regional disparities in the European Union.” Environment and Planning. 37 (10): 1837-1855.

Przeworski, Adam et al. 2000. Democracy and Development. Cambridge: Cambridge University Press. 
Putnam, Robert. 1994. Making Democracy Work: Civic Traditions in Modern Italy. Princeton: Princeton University Press.

Rifkin, Jeremy. 2004. The European Dream. Boulder: Tarcher Press.

Rittberger, Berthol. 2005. Building Europe’s Parliament. Oxford: Oxford University Press.

Rueschemeyer, Dietrich, Evelyne Huber Stephens and John D. Stephens. 1992. Capitalist Development and Democracy. Chicago: University of Chicago Press.

Sorensen, George 2007. Democracy and Democratization: Processes and Prospects in a Changing World, 3rd Edition. Boulder: Westview Press.

Tilly, Charles. 2007. Democracy. Cambridge: Cambridge University Press. 
Correct citation: Matijasevich, David. 2012. “Five Lessons from European Democracy”. Review of European and Russian Affairs 7 (1): 1-13.

Published by the Centre for European Studies at Carleton University, Ottawa, Canada.

Available online at: www.carleton.ca/rera/

RERA is an electronic academic peer-reviewed journal that publishes graduate, post-graduate, and young scholarly works. Topics relate to the European Union, its Member States, the former Soviet Union, and Central and Eastern Europe. The journal is a joint project supported by the Canada-Europe Transatlantic Dialogue-a cross-Canada research network supported by the Social Sciences and Humanities Research Council of Canada (SSHRC)—along with the Institute of European, Russian and Eurasian Studies (Carleton University) and its associated research unit, the Centre for European Studies.

RERA aims to provide an accessible forum for research, to promote high standards of research and scholarship, and to foster communication among young scholars.

\section{Contact:}

Carleton University

The Centre for European Studies

1103 Dunton Tower

1125 Colonel By Drive, Ottawa, ON

K1S 5B6Canada

Tel: +01 613 520-2600 ext. 1179; E-mail: rera-journal@carleton.ca

\section{Creative Commons License}

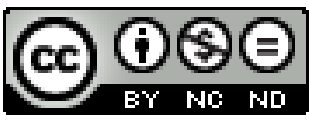

http://creativecommons.org/licenses/by-nc-nd/3.0/

This Working Paper is licensed under a Creative Commons Attribution-Non-Commercial-No Derivs 3.0 Unported License (CC BY-NC-ND 3.0).

Articles appearing in this publication may be freely quoted and reproduced provided the source is acknowledged. No use of this publication may be made for resale or other commercial purposes.

ISSN: 1718-4835 (C) 2012 The Author(s) 